\title{
Kitap Değerlendirmesi: Fahm, Khaled. In Quest of Justice: Islamic Law and Forensic Medicine in Modern Eygpt (Oakland: University of California Press, 2018), p. 377. ISBN: 978-0520279032
}

\section{Şaban Kütük * 이}

... Birgün bu önyargıyı kıracağıma dair ümidim hala vardı, her ne kadar öğrencilerin derinden iğrenmelerini ve kendileriyle konu hakkında konuştuğum ulemanın fanatik muhalefetini açık bir şekilde fark etmiş olsam da. Kendimi, ülkede yüksek bir yere sahip önemli bir kişi olan Şeyhü'l-İslam Arûsî'nin güvenini kazanmaya adadım. Anatomi konusundan söz ettiğimde hiç taviz vermedi. Onun temel argümanı, dine göre cesedin acı hissedeceği idi... ve tıp üzerine yapılan yayınların öğrencilerin eğitimi için yeterli olacağını söyledi. Ben de ona şöyle cevap verdim: Teori noksan kavramlardan fazlasını ifade etmez. Saatleri tamir eden bir saat tamircisinin onların bütün mekanizmasını bilmesine gerek yok mu? Üstelik, saatlerin nasıl çalıştığını anlamadan önce parçalarına ayırıp sonra bir araya getirmek zorunda değil mi? Bu misal onu oldukça etkiledi... ve sonunda anatomiyi çalışmak için zımni bir onay almayı başardım, fakat en üst düzeyde gizlilik şartı ile. ${ }^{1}$

Mısırda Batılı tıbbın kurucusu sayılan Dr. Antoine-Barthélémy Clot (meşhur adıyla Clot Bey) Mehmet Ali Paşa tarafindan Mısır'da bir tıbbiye kurmakla görevlendirildiğinde insan diseksiyonuna² dayalı bir tıbbî eğitim vermek istediği zaman karşılaştı̆̆ı mukavemetten hatıralarında bu şekilde bahsetmektedir. Clot Bey -kendi ifadelerine göre- bu mukavemet ile uzun süre mücadele etmiş ve sonunda anatomik diseksiyonun, ulemanın kutsala karşı bir saygısızlık olduğuna dair önyargısını kırmayı başarmıştır.

1 Khaled Fahmy, In Quest of Justice: Islamic Law and Forensic Medicine in Modern Eygpt, (Oakland: University of California Press, 2018), 3-4.

2 Kadavrayı incelemek için parçalara ayırma yöntemi.

\footnotetext{
* Sorumlu Yazar: Şaban Kütük (Arş. Gör.), Dumlupınar Üniversitesi İslami İlimler Fakültesi (ÖYP: İstanbul Üniversitesi, İlahiyat Fakültesi, Temel İslam Bilimleri Bölümü), İstanbul, Türkiye. E-posta: shabankutuk@gmail.com ORCID: 0000-0002-6467-2282 
Khaled Fahmy'nin In Quest of Justice: Islamic Law and Forensic Medicine in Modern Eygpt adlı kitabı insanı merkeze alıp, elit olmayan Misırlıların moderniteyi nasıl algıladıkları ve ona nasıl tepki verdiklerini anlamanın bir yolu olarak diseksiyon ve otopsinin meydana getirdiği değişimleri incelemektedir. Kitap bir giriş, beş ana bölüm ve sonuçtan oluşmaktadır. Fahmy, giriş kısmında modern Mısır'da tıp ile alakalı Mısır tarihyazımı konusuna değinmektedir. Fahmy'nin tespitlerine göre, Mısırlı akademik tarihçilerin ilk kuşağı, başta tıbbî olmak üzere Mısır'daki modern gelişmeler noktasında Mehmet Ali Paşa ve Clot Bey’e büyük bir rol atfetmişlerdir. Mehmet Ali Paşa öncesi Mısır hakkında genelde olumsuz bir imaj çizen bu tarihçiler, karanlık ve aydınlık metaforunu kullanarak Osmanlı hakimiyetindeki Mısır'ı cehalete saplanmış ve karanlıklar içinde derin uykulara dalmış bir belde olarak tasvir etmişlerdir. Bu tarihçilere göre Avrupa'nın gücü -Napolyon'un Mısırı işgali- ile Mısır bu derin uykudan uyanmış ve bu sayede Mısır'da modernleşme başlamıştır. Fahmy, bu bakış açısına zit olarak 19. yüzyıl Mısır'ındaki (Hidiv dönemi) gelişmeleri, Osmanlı'yı hesaba katmadan incelemenin yetersiz olacağını, zira o dönemde Mısır'ın hala Osmanlı'nın bir parçası olduğunu ve Mısır'daki siyasi, ekonomik ve toplumsal gelişmelerin imparotorluktaki gelişmeler tarafından şekillendirildiğini ifade etmektedir.

Medicine, Enlightenment and Islam başl1klı birinci bölüm modern bir tıp okulunun ve hastanenin kurulmasına Misırlıların farklı kesimlerinden gelen tepkileri incelemektedir. Mısır'da önce Ebu Z'abel T1bbıyesi kurulmuş, daha sonra bu yeni okul Kasru'l-Ayn denilen yere taşınmış ve bu bölgenin adı yeni hastanenin adı olmuştur: Kasru'l-Ayn Tibblyesi ve Hastanesi. Fahmy'nin tespitine göre tıp alanındaki gelişmeler Mısır tarih yazımında moderleşme ve aydınlamanın bir emaresi olarak gösterilmektedir. Modern hastanelerin kurulması her ne kadar modernleşme ve aydınlanma ile ilişkilendirilse de Fahmy bu hastanelerin tamamen askeri amaçla kurulduğunu, büyük oranda da bu özelliğini hiçbir zaman kaybetmediğini söylemektedir. Dolayısıyla tıbbi gelişmelerin Mısır hanedanının Osmanlı ile mücadelesi noktasında askeri reformların bir parçası olarak görülmesi gerekir.

Modernleşme ve aydınlanma ile alakalı olarak üzerinde durulan bir diğer konu ise karantina meselesidir. Karantinalar ve halkın onlara verdiği tepkiler genelde daha büyük bir aydınlanma temasının bir versiyonu olarak sunulmaktadır. Böyle bir meselede, dini dogmanın modern bilime karşı nasıl sert bir savaş başlattığını göstermek için Müslümanların kaderci anlayışı (Muslim fatalism) vurgulanmaktadır. Fakat Fahmy, bu tür bir anlayış yerine karantina mevzusunu Mısır'daki askeri gelişmelerle birlikte değerlendirmenin daha isabetli olacağını düşünmektedir. Zira Mehmet Ali Paşa savaş gücünü kaybetmemek için karantinaları tamamen askeri odaklı olarak uygulamıştır. Fahmy bu kısımda, kısaca dönemin Mısır 
ulemasının diseksiyon ve otopsiye karşı bakışını da incelemiş ve Clot Bey'in iddia ettiği gibi ulemanın cesedin acı çektiğini düşündügüne dair herhangi bir kanıtın olmadığını söylemiştir. Fahmy’e göre ulemanın diseksiyon ve otopsiye karşı tepkilerinin temelinde, otopsi sebebiyle cenaze işlemlerinin gecikmesi endişesi yer almaktadır; bu tepkilerin iddia edilenin aksine bedenin kutsallığ alakası bulunmamaktadır.

Siyasa: The Forgotten Code adlı ikinci bölümde Fahmy, siyaset ve fikıh sistemlerini incelemektedir. Fahmy'nin ifadesine göre siyaset sistemi ve meclisi, on dokuzuncu yıl Mısır hukuk yazımında görmezden gelinmektedir. Her ne kadar istisnai olarak bazı yazarlar siyaset sistemine değinseler de siyaseti yetersiz ve karışı bürokrasinin bir işareti olarak tasvir etmektedirler. Fahmy'nin bu bölümdeki temel amacı, Mısır hukuk tarihi yazımında henüz arşiv ve mahkeme kayıtları dikkate alınarak detaylı bir şekilde ele alınmayan, cinayet meselelerinde siyaset ve fikıh işbirliğini incelemektir. Fahmy'e göre fikıh sisteminin ve mahkemelerin dinî, siyaset meclislerinin ise seküler olduğunu iddia etmek gerçeği yansıtmamaktadır. Aksine bu iki sistem, iş birliği içerisinde çalışan ve birbirini tamamlayan iki sistemdir. Cinayet meselelerinde ise Fahmy'e göre iki kurum arasındaki temel fark şudur: Fıkıh cinayet suçlularını cezalandırmayı kul hakkı olarak tanımlamakta ve dava açma hakkını sadece maktulün mirasçılarına vermektedir. Siyasette ise dava ve şikayeti devlet yani polisin başlatma hakkı vardır. Başka bir deyişle fikıh cinayet meselesini özel hukukun bir parçası olarak görürken siyaset, toplumun ve devletin de hakkı olduğunu ve cinayet melesesinin şahıslara bırakılmaması gerektiği konusunda 1srar etmektedir. Aralarındaki bu farka rağmen cinayet meselelerinde bu iki kurum iş birliği içinde çalışmıştır.

Law in the Market: Hisba and Forensic Chemistry adlı bölümde Fahmy, hisbe kurumunu, on dokuzuncu yüzyıl Mısır'ındaki kimyagerler ile ilişkisini ve muhtesibten polis, kamu hijyenistleri ve kimyagerlere geçişin etkilerini incelemektedir. Fahmy'e göre hisbe kurumunun toplumsal barışı korumak ve bu uğurda şiddete başvurma dahil olmak üzere çeşitli önlemler alma noktasında siyaset ile sıkı bir bağlantısı vardır. Mısır'daki hisbe kurumu 1837 yılında kaldırılmış ve zamanla yerini kimyagerler almıştır. Özellikle muhtesiblerin en önemli görevlerinden biri olan yiyeceklerin kontrolü Kasru'l-Ayn Tıp okuluna geçmiştir. Çarşı ve pazarlarda yiyeceklerin kontrolünü üstlenen "sağlık polisleri” şüpheli buldukları yiyeceklerden numune alarak bu okuldaki kimyagerlere göndermekte, onlar da analizleri doğrultusunda bulgularını adli bir rapor şeklinde polise yazmaktaydı. Fahmy'nin belirttiğine göre bu gelişme ceza hukuku ile alakalı başka bir değişimi de beraberinde getirmiştir. Zira özellikle polisin alkol, uyuşturucu ve zehir vakalarındaki incelemelerinde kimya merkezi rol almaya başlamıştır. 
Justice without Pain başlıklı bölümde Fahmy tıbbi pratiklerin şerî mahkemeler ve siyaset alanlarındaki kullanımın incelemektedir. Tıbbi pratiklerin şerî mahkemelerde kabulü siyaset meclislerindeki kabulünden oldukça farklı olmuştur. Fahmy’ye göre bu konu ile alakalı önemli sorulardan bir tanesi şudur: Tıbbi pratikler mahkemede şahitlik yapmanın bir türü olabilir mi? Yani davalarda tıp uzmanlarının vermiş olduğu bilgilerin delil değeri nedir? Fıkıh ilminde, mahkemede şahitlik yapacak doktorun işinde ehil olması, muhtesibin doktorları gözetlemesi gibi şartlar vardır. Ayrıca muhtesibe, doktorların Hipokrat yemini etmesini, hastalarına zehir veya zararlı maddeleri ilaç olarak vermemesini sağlaması gibi vazifeler yüklenmiştir. Özellikle kasden öldürme gibi ölüm cezasının verilebileceği durumlarda kâdî, ölüm sebebini tespit etmede veyahut sadece doktorların bilebileceği baş yaralama meselelerinde doktorların şahitliğini isteyebilir. Siyaset meclislerinde ise tıbbi uzmanlığın kullanımı fikıhtan oldukça farklı olmuştur. Birincisi, yeni tıbbi uzmanlık kemiklerin kırılması, yaralanma sebeplerinin tespiti ve ölüm nedenini belirlemede çok daha ileri bir seviyedeydi. İkincisi ise mahkemede şahitlik meselesi ile alakalıdır. Kâdî mahkemelerinde doktorların sözlü olarak şahitlik yapmaları istenirken siyaset meclislerinde doktorlar incelemelerinin sonucunu yazılı rapor şeklinde sunuyorlardı. $\mathrm{Bu}$ ise, özellikle olayı bizzat gören şahitlerin yanında raporların da önemli birer delil olma gücü kazanmasına sebep oldu. Ayrıca doktorlar mahkemelerde dava sürecinin bir parçası değilken siyaset meclislerindeki doktorlar bizzat bu mecliste görev yapan adli tıp uzmanı idiler. Fahmy, bu farkların fikhın tıbbi uzmanlığı bir delil olarak kabul etmediği manasına gelmediğini, sadece Kasru'l-Ayn'daki doktorların raporlarının daha güvenilir ve muteber deliller sunduğu şekilde anlaşılması gerektiğini ifade etmektedir.

Sonuç olarak Khaled Fahmy'nin bu eseri Mehmet Ali Paşa ile başlayan Mısır'ın yeni dönemindeki gelişmeleri adli tıp temelinde çok farklı açılardan inceleyen başarılı bir kitaptır. Adli tıptaki gelişmeler -diseksiyon ve otopsi- sonucunda özellikle yaralama ve öldürme suçu davalarında, adli tıp uzmanlarının hazırladığ 1 raporların soruşturma ve verilecek cezanın tespiti noktasında ne tür değişimler getirdiğini göstermeye çalışmıştır. Fahmy'e göre en büyük değişimlerden biri artık mahkemede sözlü şahitlik kadar yazılı materyallerin (adli tıp raporları) de güçlü birer delil olarak kabul edilmesidir. Bununla birlikte Fahmy, her ne kadar on dokuzuncu yüzyılda Mısır'daki gelişmeleri merkezi, yani Osmanlı'yı göz önünde bulundurmadan incelemenin eksik ve yetersiz olacağını söylese de o dönem Mısır'ının merkez ile bağlantısını ve bu gelişmelerde merkezin rolünü ve tepkisini ele almamıştır. Nihayetinde bu çalışma, sadece ceza hukuku literatürüne değil sosyal ve toplumsal çalışma alanlarına da özgün bir katkıdır. 